\title{
ENCUENTROS CON MANUEL PUIG
}

\author{
POR \\ JORGELINA CORBATTA \\ University of Pittsburgh
}

Durante los meses de agosto y septiembre de 1979 Manuel Puig estuvo en Colombia. Viajó para asistir al «Encuentro de Escritores Hispanoamericanos», celebrado en Cali en la primera semana de agosto, y al que también concurrieron el escritor español Camilo José Cela, el mexicano Juan Rulfo, los colombianos Mejía Vallejo, Alvarez Gardeazábal, Soto Aparicio, Fanny Buitrago y los críticos literarios norteamericanos Seymour Menton y Raymond Williams. Parte del grupo viajó luego a un encuentro similar en Medellín. De allí Puig pasó a Cartagena, donde permaneció casi un mes. Regresó a Medellín en septiembre. Llegó solo y ya $\sin$ la necesidad de esforzarse, como la primera vez, para recortarse dentro de aquel grupo un tanto espectacular y vocinglero. Estuvo una semana entre nosotros y recorrimos juntos gran parte del itinerario.

En el Paraninfo del antiguo edificio de la Universidad de Antioquía volvió a evocar su infancia en un pueblecito desolado de la pampa cuyo oasis lo constituía el cine, única vía de escape de una realidad familiar y pueblerina que rechazaba; sus evasiones posteriores, cada vez más lejos, Buenos Aires, Cinecittà, pero igualmente infructuosas; el inevitable regreso a sí mismo, a lo propio, la literatura, su gente. Supimos también de sus piruetas para evitar la tercera persona, forma literaria de asumir una autoridad de la que no se sentía capaz; el feliz aterrizaje en el monólogo interior; los vuelos en busca de otras formas expresivas. Esta primera exposición nos permitió entrever un esbozo de teoría del habla de los argentinos de primera generación - hijos de inmigrantes campesinos en su mayoría- que tomaron sus modelos de la calle: el tango, los boleros, el folletín, las películas y el radioteatro. Hubo asimismo una reflexión acerca del origen de la novela contemporánea, Freud, y una consecuencia alentadora, el vasto campo a explorar por el nove- 
lista a partir de sus descubrimientos; un deslinde esclarecedor entre literatura y cine; una caracterización optimista de la literatura hispanoamericana respecto de la europea y norteamericana. Volvimos a escucharlo respondiendo preguntas de mis alumnos de «Sociología de la Literatura» en la Universidad de Antioquía. Frente a ellos retomó una de sus preocupaciones fundamentales, la Argentina, y uno de sus aspectos más complejos y desconcertantes, el peronismo. Habló también de The Buenos Aires Affair, en apariencia su novela preferida a la vez que la más controvertida críticamente; de su preocupación por el sexo y acerca del recurso técnico adoptado para resolver el problema de la exposición de la homosexualidad en El beso de la mujer araña (las notas a pie de página que amplían el tema, encarnado en la figura de Molina, mediante la transcripción de diferentes teorías); de su gusto por los géneros menores, que comparte con sus personajes; del propósito que guió la escritura de Pubis angelical. Nuevamente ante gente joven, los participantes del taller literario de la Biblioteca Pública Piloto, escuchamos sus pacientes respuestas dadas en ocasión de plantearse la relación entre el ejercicio del periodismo y la creación literaria (Puig no cree que aquél influya benéficamente en ésta); acerca de los vericuetos de los concursos literarios, la concesión de los premios y la edición de las obras; su enfática afirmación sobre la necesidad de concentrar esfuerzos y bucear en el interior de uno mismo para encontrar lo propio y expresarlo. El fin de semana, finalmente, transcurrió en un ámbito muy grato: la serena y acogedora finca de Quirama, el estimulante frío de Río Negro. En esta ocasión no fue ya «La primera persona singular» (título de su exposición en el Paraninfo) ni lo sociológico vinculado con su novelística ni la transmisión de su experiencia a jóvenes que escriben -fragmentariamente considerado-, sino que, a lo largo de este último encuentro, titulado «En búsqueda de una voz propia», todo lo anterior volvió a plantearse más unitariamente, enriquecido por una mayor confianza, cierto humor y la liberación de la tiranía del horario. Allí, como fin del itinerario, tuvo lugar este reportaje, que reproduzco a continuación.

IC: ¿Qué papel desempeña el lector respecto de tu obra? ¿Vos pensás en el futuro lector cuando estás escribiendo una novela? ¿Ha influido el gusto de los lectores, su preferencia por alguna novela tuya en particular, en la elaboración de las siguientes?

MP: Yo siempre tengo presente a los lectores. Yo escribo para un lector con mis limitaciones. Un lector con ciertas dificultades para la concentración en la lectura, que, en mi caso, proviene de mi formación 
como espectador cinematográfico. Por eso trato de no pedir esfuerzos especiales de la atención por parte del lector.

JC: ¿Pero vos no pensás que esos cambios, esas historias paralelas o una misma historia contada en diferentes niveles, exigen...?

MP: Exigen una reflexión, que es otro tipo de operación mental. A mí lo que más me cuesta es seguir una prosa que no tiene un hilo determinado, la reiteración me puede molestar muchísimo.

JC: Yo sigo pensando que, si bien los planteamientos básicos son sencillos, es preciso desentrañarlos a lo largo de una formulación compleja. Por ejemplo, los monólogos interiores de La traición de Rita Hayworth, la multiplicidad de indicios imbricados en la trama pseudopolicial de The Buenos Aires Affair, la relación entre las peliculas contadas y las fantasias de los protagonistas en El beso de la mujer araña, el desdoblamiento de Ana en Pubis angelical. En ese sentido...

MP: Yo no quiero decir que tenga en cuenta a un lector tonto, sino a un lector con cierta exigencia de agilidad. Creo que el cine es eso, ante todo, lo que nos ha provocado, una exigencia de agilidad. Hay cierta morosidad que a mí me puede poner nervioso en una prosa.

JC: Proust, por ejemplo.

MP: No, no sería el ejemplo más adecuado.

JC: ¿Cuál entonces?

MP: Bueno, cierta novela española de principios de siglo. Pereda, por ejemplo. Además, yo he escrito cada una de mis novelas para convencer a una persona en especial de algo. La traición de Rita Hayworth "a escribí para convencer a un amigo de algo y Boquitas para convencer a un enemigo de algo.

JC: ¿Vos decías antes que a un crítico?

MP: Sí, a un crítico argentino que tenía un gran desprecio por los géneros menores.

JC: ¿Y vos conociste ese desprecio a partir de la critica a La traición de Rita Hayworth?

MP: No, no. Estas novelas salieron casi juntas. La traición... tardó tanto. No. Me fue presentado a mi llegada a Argentina y yo sentí una pedantería, un gusto muy opuesto al mío, y eso me estimuló.

Siguiendo con lo del lector, vos me preguntabas si ese lector, con su respuesta, había condicionado la obra siguiente. No, para nada. La obra que tuvo mucha aceptación por parte de los lectores fue Boquitas pintadas $^{1}, \mathrm{y}$ todos esperaban que yo siguiera en esa línea. $\mathrm{Y}$, sin em-

\footnotetext{
${ }^{1}$ Boquitas pintadas es indudablemente, hasta el momento, la novela suya más leída. Cabe recordar incluso que fue llevada al cine por Leopoldo Torre Nilsson.
} 
bargo, la cambié totalmente porque me interesaba otro tipo de investigación y por eso escribí The Buenos Aires Affair, que no obtuvo el beneplácito del lector, pero que no por eso yo condené. No reniego de esta obra, al contrario, me interesa siempre seguir por esa línea.

JC: Y esa linea sería...

MP: Una línea de investigación en el error argentino.

JC: Entendiendo por error...

MP: Error político, error sexual ${ }^{2}$.

JC: ¿Y respecto de la crítica?

MP: La crítica sobre mi obra no me ha ayudado para nada. Al con-

Al respecto dice Manuel Puig en una entrevista con Manuel Osorio: «Torre Nilsson me habló dos años antes de concretarse el asunto y a mí no me entusiasmaba la idea, estaba convencido de que el posible atractivo de la novela residía en sus recursos puramente literarios y que, quitado eso, iba a quedar una anécdota no demasiado interesante. Creo que esa novela vive de su estructura, la cual no es precisamente cinematográfica. Veía la imposibilidad de repensarla, la obra había nacido ya de ese modo, y desmontarla y volverla a armar en términos cinematográficos, no sé, no lo veía posible. Pasó el tiempo y Leopoldo me volvió a hablar, me dijo que justamente lo que le interesaba era esa estructura literaria, ver cómo daría en el cine. De ese modo yo me sentí más tranquilo, le propuse entonces un esqueleto de guión, siguiendo la línea de la novela, y estuvo de acuerdo. En pocas semanas hice el guión, claro, bajo su supervisión. Siempre supe que iba a ser una película de Torre Nilsson, no una película mía. Si yo hubiera querido expresarme totalmente habría tratado de filmarlo yo, pero no era esto lo que me interesaba, absorbido como estaba por mi cuarta novela. Traté de complacerlo a él y, al mismo tiempo, hacer algo que no me disgustara. Yo ya no estaba en Buenos Aires en el 74, cuando se filmó» (Semanario Cultural, Revista de El Pueblo, Cali, 6-VIII-78).

${ }^{2}$ Cf. Emir Rodríguez Monegal en «La traición de Rita Hayworth. Una tarea de desmitificación» y en «Los sueños de Evita». A propósito de la última novela de Puig expone, muy acertadamente, esa doble problemática — política y sexualabordada en las dos primeras novelas. «Es la resistencia ante una exploración implacable de algunos mitos básicos del Río de la Plata. Por primera vez en aquella zona (que abarca también a mi patria, el Uruguay) un escritor se atreve a mostrar qué es lo que se barre todos los días debajo de las alfombras del liberalismo religioso, de una cultura a la europea, de unos principios muy declarados de modernidad y desprejuicio. La frustración sexual es el instrumento que sirve a Manuel Puig para hacer estallar todos los mitos básicos: desde el mito familiar hasta los de la sociedad. Si la mayor parte de los personajes son niños o adolescentes, o se comportan como niños grandes e irresponsables, es porque ésa es la edad mental y afectiva que domina en aquella zona. Si el sexo adquiere caracteres violentos y sórdidos es porque la frustración sexual está en la base de las relaciones entre aquellos hombres y mujeres. [...] Hay otra dimensión de la mediocridad que el libro da en forma muy sutil: es la mediocridad política.» E. Rodríguez Monegal, Narradores de esta América (Buenos Aires: Alfa, 1974), pp. 365 $y$ siguientes. 
trario, yo creo que han sido en su mayoría erradas las interpretaciones y me han hecho perder tiempo, nada más.

JC: Pero... ¿vos leés la crítica, leés la crítica y te interesa?

MP: Sí, sí, cómo no. Además, no le he merecido a la crítica, todavía, trabajos muy a fondo; se está recién ahora empezando a hacer una crítica un poco más detenida. He tenido mucha crítica, pero esa de semanarios, de periódicos, que es una crítica bastante apresurada.

JC: ¿No notás cierta línea de análisis que se repite, por ejemplo, el análisis desde el ángulo psicoanalítico?

MP: No sé, no sabría decirte. Pero no se han tomado gran trabajo realmente. Yo no he sentido el aporte de la crítica en ese sentido: que me hayan ayudado a esclarecerme cosas, por desgracia, no.

JC: ¿Y los amigos?

MP: Los amigos, sí, muchísimo.

JC: Leyendo un reportaje a Cabrera Infante me entero de que él ha participado activamente en la versión al inglés y al francés (luchando en este último caso con la reiterada afirmación del traductor respecto de su versión "Ca, c'est ne pas français») de Tres tristes tigres. Me imagino que, en general, las dificultades de la traducción son muchas, y en tu caso, una obra escrita en "argentino», todavia mayores.

MP: Yo colaboro muchísimo con los traductores de los idiomas que sé, que son inglés, francés, italiano y portugués. Te doy un ejemplo de cambios necesarios: hay un capítulo de Boquitas pintadas que está resuelto a través de una tirada de cartas de una gitana. En Francia e Inglaterra, por ejemplo, no se conocen los naipes españoles, de modo que tuve que reescribirlo cambiando todas las imágenes que se desprenden de las figuras de los naipes con naipes de póquer. Así que fue una reescritura.

JC: ¿Y lo que vos decías en clase el otro día respecto de los acapites?

MP: Sí, sí. Sobre todo me dieron mucho trabajo los epígrafes de letras de Le Pera. A mí me encantan esas letras, pero su encanto poético se deriva, casi exclusivamente, de la musicalidad, de la sonoridad. Le Pera no tiene imágenes muy fuertes que "pásen» la traducción. Por eso los cambié por letras de Homero Manzi que sí tienen imágenes que quedan en la traducción. No quiero decir con esto que prefiera un letrista a otro. No. Son dos gustos diferentes. Le Pera es más años treinta; además, se adecúa más a la novela pero no quedaba nada en la traducción.

JC: ¿Algún otro caso, aparte de la tirada de cartas y los epígrafes? MP: Oh sí, muchos, muchísimos. Ha habido muchísimas reescritu- 
ras. ¡Para qué hablar de $E l$ beso de la mujer araña! Tú sabes que el diálogo-teatro, traducir teatro implica siempre adaptar de una lengua a otra - ya en Estados Unidos nunca se dice «traducción de fulano», sino "adaptación al inglés de fulano»- porque, digamos, en italiano el modo de expresarse es muy similar al argentino, ¿no?, pasó, pasó casi íntegramente; en francés ya menos y en inglés hubo que reescribir muchísimo. Para producir las mismas tensiones, porque las mismas cosas se dicen de modo muy diferente, no sólo con el léxico inglés, sino con otras imágenes, con otros «dichos», otros modismos. Es muy difícil traducir.

JC: Me gustaría saber cuáles son tus modelos literarios, tus escritores favoritos. Se sabe mucho acerca de tu afición por determinado tipo de cine, por los boleros y los tangos, pero poco o nada de tus predilecciones literarias. Incluso un crítico llega a afirmar: «Puig es sin duda el que menos parece deber, no ya a la tradición literaria inmediata, sino pura y simplemente a cualquier clase de tradición literarias ${ }^{3}$.

MP: No tengo modelos literarios evidentes, porque no ha habido, creo, influencias literarias muy grandes en mi vida. Ese espacio está ocupado por las influencias cinematográficas. Yo creo que, si alguien se tomara el trabajo, va a encontrar influencias de Lubitsch en ciertas estructuras mías, de Von Sternberg en ese afán por ciertas atmósferas, Hitchcock mucho, pero lo demás... no sé. A mí, de los autores modernos me gustan mucho, mucho, Kafka y Faulkner. Pero, de todos modos, no es que los haya leído exhaustiva ni apasionadamente.

JC: ¿Y te gustan... por la atmósfera, por la técnica, por la temática?

MP: Me gusta la poesía de Faulkner, la belleza. No; la temática, no, para nada.

JC: ¿Podrian haber sido un modelo, en un momento dado, los monólogos de Mientras agonizo?

MP: Nunca lo leí. Tuve que hojearlo este año porque en el taller del City College se discutió esa obra con los alumnos. Una muchacha sacó a relucir eso y tuve que darle una ojeada.

JC: ¿Y con Kafka?

MP: Bueno, creo que él es el que mejor ilustra toda esa cuestión que a mí me interesa tanto: la opresión del medio ambiente sobre el individuo, la cuestión inconsciente, el mundo de cárceles internas que llevamos sin saberlo. Esa red que tenemos cada uno de represiones construida adentro. Pero a mí me interesa referirlo todo siempre directamente

${ }^{3}$ Pere Gimferrer, «Aproximaciones a Manuel Puig» (Plural, México, junio de 1976), pp. 21 y ss. 
a la realidad. Kafka se deja llevar por la fantasía; a mí me interesa localizarlo de algún modo.

JC: Otro aspecto en el que los criticos no se han puesto de acuerdo: ¿hay en tu obra una intención paródica o vos compartís afectivamente el mundo de tus personajes?

MP: Yo no tengo una intención paródica. Uso a veces cierto humor porque mis temas son tan ácidos, tan mezquinos, que sería realmente muy árido un desarrollo de todo eso sin un elemento de humor ${ }^{4}$. Son historias en general muy sombrías las mías, creo que se necesita un ingrediente de humor. Además, en la vida hay humor, ¿verdad?, y en los argentinos - aunque cueste creerlo- también. Creo que la inclusión del humor no es un forzamiento, sino que realmente es un elemento de la realidad. Volviendo a lo de parodia, parodia significa burla, y yo no me burlo de mis personajes, comparto con ellos una cantidad de cuestiones, su lenguaje, sus gustos ${ }^{5}$.

${ }^{4} \mathrm{Al}$ respecto, refiriéndose a $\mathrm{El}$ beso de la mujer araña, dice Julio Miranda: «Las vidas siguen ofreciéndose en su irrisoria desolación, en su más triste banalidad, y cabría preguntarse qué existencia humana resistiría a la manipulación narrativa de Puig sin mostrarse como fracaso absoluto», en "Manuel Puig: la exploración del lenguaje» (Zona Franca, Caracas, 51-54, mayo-junio de 1977), p. 53.

${ }^{5}$ En el artículo citado dice Pere Gimferrer: «En el sistema referencial empleado por Puig no hay lugar para la ironía; hombre entre los hombres, el autor no se siente superior a ninguno. La cursilería del diario de Esther en 1974, en La traición de Rita Hayworth, o de las películas que Molina relata a Arregui en El beso de la mujer araña [...], no son objeto de desdén por parte del autor: sus personajes, en el orden de los sentimientos, creen en lo que dicen, y su alienación podría despertar compasión pero no sarcasmo» (p. 21).

Severo Sarduy, novelista emparentado con Puig en algunos aspectos, adjudica a Boquitas pintadas el calificativo de "parodia» (según la definición de Bakhtine); aquélla tendría «como un trazo específico la mezcla de géneros, la intrusión, el injerto de un tipo de discurso en otro, la abolición de la autonomía narrativa, epistolar, crítica, etc. Bakhtine subraya que lo importante es que, del modelo de base [...], la obra paródica es a la vez una apoteosis y una irrisión. A la vez que un folletín, casi perfectamente conforme al género, Boquitas pintadas es la transgresión paródica, el doble irrisorio del folletín», en «Notas a las notas a las notas: A propósito de Manuel Puig» (Revista Iberoamericana, vol. XXXVII, juliodiciembre de 1971, núm. 76-77), pp. 556-557.

Otro autor, Gilberto Triviños, retoma la noción de parodia, como apoteosis e irrisión, aplicada a Boquitas pintadas, y la amplía mediante el análisis de los procedimientos utilizados por Puig para destruir lo verosímil folletinesco. Esos procedimientos son: relato en el relato (la serie radioteatral «El capitán herido»), uso del suspenso y negación del «final feliz» (desplazado de su realización en lo real hacia lo imaginario de los personajes), destrucción del mito que elimina las contradicciones de la realidad, heterogeneidad de los materiales (estructura de bricolage), desintegración del narrador omnisciente, apertura. Dice Triviños: «Cervantes, Flaubert y Puig, en efecto, destruyen las convenciones de la literatura 
JC: En el transcurso de un reportaje imaginario para Harper's Bazar, Gladys explica su concepto de arte: «Esa noche me sentí más sola que nunca, presa de la desesperación volví al chalet y tuve, entre desvarios, la inspiración. No pude dormir, a las cinco el amanecer me sorprendió en la playa, recogiendo por primera vez los desechos que había dejado la marejada sobre la arena. La resaca, me atrevía solamente a amar la resaca, otra cosa era demasiado pretender. Volví a casa y empecé a hablar -en yoz muy baja para no despertar a mamá- con una zapatilla olvidada, con una gorra de baño hecha jirones, con una hoja rota de diario, y me puse a tocarlas y a escuchar sus voces. La obra era ésa, reunir objetos despreciados para compartir con ellos un momento de la vida, o la vida misma. Esa era la obra» '. Eso me recuerda la definición de "bricolage» de Lévi Strauss: «El 'bricoleur' no opera con materias primas sino ya elaboradas, con fragmentos de obras, con sobras y trozos, [...] se dirige a una colección de residuos de obras humanas, es decir, a un subconjunto de la cultura. La poesía del bricolage le viene también y sobre todo de que no se limita a realizar o ejecutar; 'habla', no solamente con las cosas, sino también por medio de las cosas: contando, por intermedio de la elección que efectúa entre posibles limitados, el carácter y la vida de su autor» (El pensamiento salvaje). ¿Qué relación existiría entre lo anterior y tu concepto de arte?

MP: Yo comparto totalmente el concepto de arte de Gladys ${ }^{7}$.

IC: Volviendo a The Buenos Aires Affair, quisiera que hablaras del

consoladora de su tiempo mediante un proceso semejante de irrisión y apoteosis de los posibles tolerados en los textos que reescriben. Sus obras tienen en este nivel un sentido destructivo a través del cual deshacen un sistema de convenciones: el de la literatura caballeresca, El Quijote; el de la romántica, Madame Bovary; el de la folletinesca, Boquitas pintadas», en «La destrucción del verosímil folletinesco en Boquitas pintadas» (Texto critico, Centro de Investigaciones Lingüístico-literarias, Universidad Veracruzana, Xalapa, año IV, núm. 9, enero-abril de 1978), p. 129.

Otro artículo, que retoma parcialmente el planteamiento de Sarduy y la noción de parodia de Mikhail Bakhtine, es el de Margery Safir, «Mitologia: otro nivel de metalenguaje en Boquitas pintadas» (Revista Iberoamericana, núm. 90, enero-marzo de 1975), pp. 52 y ss. En él la autora analiza la naturaleza de la parodia en la novela en relación con los diferentes niveles míticos, como injertos -que se contradicen e invierten el modelo- dentro del texto; aborda asimismo las diferentes lecturas que la obra posibilita de acuerdo al mito pretextual con el que el lector se identifique.

${ }_{6}^{6}$ M. Puig, The Buenos Aires Affair (Barcelona: Seix Barral, 1977), p. 108.

${ }^{7}$ Respecto de la relación entre el discurso de las obras de Gladys y el discurso de Molina en El beso de la mujer araña, cf. Roberto Echavarren, «El beso de la mujer araña y las metáforas del sujeto» (Revista Iberoamericana, núms. 102103, enero-junio de 1978), pp. 66 y ss. 
último capítulo, en el que la introducción de esa pareja joven, con un niño pequeño, satisfecha y feliz, pareciera responder al intento de equilibrar un poco la frustración del resto de los personajes de la novela. Como una especie de final feliz.

MP: A lo largo de su vida, el personaje de la protagonista ha forjado diferentes fantasías que de algún modo la han sostenido y que de algún modo, en algún momento, se le han desmoronado. Ella va a intentar suicidio en un momento en que nada puede sostenerse, salvarse, $y$, en ese momento, se produce una nueva fantasía, la despierta esta pareja joven con un niño que está en el departamento vecino. Gladys, la protagonista, es una muchacha que vive de imágenes míticas, necesita siempre de estas fantasías extrañas y se salva porque logra forjar una más en ese momento crítico.

JC: Cuando lei la novela los vi como otros personajes, reales, con los que Gladys puede iniciar una comunicación...

MP: Ante todo es importante que ella supere ese trance, y de esta pareja yo doy dos versiones: la que le sirve a Gladys para elaborar una fantasía, y la otra, la real, la de las preocupaciones que tienen estos dos protagonistas en un acto amoroso perfecto. La muchacha no es lo que Gladys se imagina, no es una criatura suspendida en el espacio del placer total, sino alguien con temores. Justamente el temor de perder algo. Quien no tiene nada se encuentra en la desolación, tiene un resentimiento por la gente que sí logra cosas. Ella no tiene nada y la carencia es lo que la angustia, ¿no? Sin embargo, a la muchacha vecina lo que la angustia es el miedo de perder lo que tiene.

Entonces... lo que me importaba era, de algún modo, hacer que la protagonista continuase porque ella, aparentemente, es un personaje débil, pero la realidad es que tiene unas posibilidades de resurgimiento muy propias de la persona que ha sido criada en la zozobra y en la inseguridad afectivas.

JC: ¿Habría entonces cierto tono optimista?

MP: Bueno, peor de lo que está Gladys en ese momento, difícil que vuelva a estarlo; entonces, si supera ese trance, quiere decir que su capacidad de recuperación es muy grande.

JC: ¿Qué podrías decir de la incorporación de Esther o de Cobito en tu primera novela? ¿Responde al deseo de dar una visión totalizadora del país, aparte del rescate de lo autobiográfico?

MP: Ese afán de incorporar un Cobito o una niña peronista ${ }^{8}$ no pro-

\footnotetext{
${ }^{8}$ Con referencia a esos personajes, y en especial Esther, cf. Alfred Mac Adam, «Las crónicas de Manuel Puig» (Cuadernos Hispanoamericanos, núm. 274, Madrid, abril de 1973), pp. 97 y ss.
} 
viene de una preocupación por abarcar un espectro argentino más completo, sino que eran problemas míos, ¿no? Yo estaba inmerso en ese mundo del primer peronismo y lo he estado en el segundo y en el tercero, pero la motivación siempre es personal, sí, sí.

JC: Vos hablabas de la relación de tu obra con un inconsciente colectivo.

MP: Yo siempre hablo de mi preocupación por los contenidos del inconsciente colectivo. Me preoctupan, claro, los contenidos de mi inconsciente no compartible pero supongo que hay un gran espacio ocupado en mí por el inconsciente colectivo y en la medida en que dé con estos contenidos voy a poder interesar al lector, porque van a ser elementos comunes a los dos. De todos modos, to no colectivo, lo mío intransferible también me interesa. Yo creo, además, que el inconsciente colectivo tiene que ver con el interés que despierte la obra como temática. Cuando yo trate de cosas mías que, al mismo tiempo, son problemas no resueltos de una gran mayoría, voy a lograr atraer más el interés del lector, pero... en cuanto a la realización estética, creo que es ese componente inconsciente, intransferible, mío, único, el que más puede operar. Creo que la originalidad de un autor depende mucho de que esa zona suya se logre expresar.

La temática sí tiene que ver con el inconsciente colectivo: va a interesar la novela en la medida en que esa temática se comparta, ¿no?, y de que yo logre aclararle problemas a mucha gente, pero... también va a ser lo mío más atractivo, mi obra, en cuanto esté realizada según un gusto mío propio, es decir, en la medida en que yo encuentre una voz mía única, ¿comprendes? Eso no está tan condicionado por el inconsciente colectivo sino por componentes inconscientes míos únicos. Es decir, cada uno tiene una parte individual intransferible...

JC.: ... que determina un tono individual, intransferible...

MP: ... y un gusto, un gusto, una tonalidad. Entonces creo que esa parte es la que puede mejor reflejarse en la forma de la obra mientras que el contenido lo da la parte del inconsciente colectivo.

JC: Lucien Goldmann habla del sujeto colectivo de la creación cultural. El autor sólo sería el portavoz «lúcido», podríamos decir, o sea, que es aquel capaz de detectar mejor y de formular con la mayor felicidad posible (ya que produce una obra de arte) la visión del mundo de un grupo social. ¿Sería posible pensar en un grupo de escritores, extensible también a otras artes, preocupados por la inautenticidad, la alienación, la subordinación del hombre contemporáneo a pautas que lo mutilan, le quitan la posibilidad de crecer totalmente, ya sean esas mutilaciones de indole política, económica, sexual o todas ellas a la vez? 
¿Por qué Fuentes, Puig, Sánchez, Cabrera Infante, Sarduy abordan los mass-media y los introducen en su obra?

MP: Bueno, yo creo que comparto con ellos preoctupaciones pero no comparto la forma. Mi estilo, no mi temática ni mis preocupaciones, no tiene que ver con Fuentes, no tiene que ver con Sarduy ni con Cabrera Infante ${ }^{9}$ ni con Sánchez.

JC: ¿Con quién tendría que ver, si tuvieras que filiarte con alguien?

MP: No sé, en literatura no sé.

$\mathrm{JC}:$ ¿Y en cine?

MP: En cine yo creo que hay afinidades con Von Sternberg, con Dishonoured de Von Sternberg. Es una película que, cuando la veo, ¡ay, qué cerca está de mis cosas! En castellano se llamaba Fatalidad, 1932, con Marlene Dietrich.

JC: ¿Qué relación hay entre tu obra y el pop-art, el kitsch, el camp?

MP: A mí me interesa sobremanera el territorio del mal gusto ${ }^{10}$, porque creo que el temor a caer en un soi disant mal gusto nos impide el recorrido de zonas especiales, que pueden estar más allá del mal gusto. Me interesa muchísimo ver qué pasa por allí, dejarme llevar por ciertas intuiciones. Por ejemplo, en la truculencia del tango ${ }^{11}$ yo veo la posibilidad de una forma de poesía diferente. Me interesa también el sobresentimentalismo de cierto cine: a ver qué hay más allá de eso, a qué responde esa necesidad, qué satisface eso en el público y qué habría más allá de eso. Entregándome a la experiencia del sobresentimentalismo, ¿qué viene después...? Ese no dejarse llevar por ciertas actitudes, a ver, a ver, ¿por qué no, por qué no?

JC: Explorar ahi, ¿no? Vos hablabas de investigar...

MP: Sí, sí. Investigar las diferentes manifestaciones de lo que se llama mal gusto. Pero, claro, no fríamente, ¿verdad? A mí me interesa el mal gusto en la medida en que yo gozo con un tango truculento, en que yo gozo con una película para hacer llorar.

JC: ¿Y los boleros?

MP: Los boleros... Por ejemplo, hay boleros kitsch de Agustín Lara que, no sé, a mí me tocan cierta fibra que... ¿qué pasa? Simple-

' Cf. Monserrat Ordóñez, "Tres tristes tigres y La traición de Rita Hayworth» (Eco, núm. 173, Bogotá, marzo de 1975), pp. 516 y ss.

${ }^{10}$ Puig se explaya sobre este punto en «Conversación con Manuel Puig: la redención de la cursilería», por Danubio Torres Fierro (Eco, op. cit.), pp. 507 y ss.

${ }^{11}$ «Alma orillera y vocabulario de todos hubo en la vivaracha milonga; cursilería internacional y vocabulario forajido hay en el tango.» J. L. Borges, «El idioma de los argentinos», en El lenguaje de Buenos Aires (Buenos Aires: Emecé, 1968), p. 17. 
mente con reírse y tomarlo en broma no creo que esté la operación completa, ¿verdad? Pareciera que a mí me satisfacen otras necesidades, ¿y cuáles son y en qué medida los demás las tienen, y por qué, qué pasa con ellas? Pero no detenerse ante el umbral de todo eso, ¿comprendes?, y descartarlo con una ironía.

JC: Otra cosa. Si tu literatura reelabora mitos de nuestra época $-y$ la característica de esos mitos, como señala Dorfles, es el rápido consumo y la obsolescencia ${ }^{12}$-, ino significaría ello cierto grado de incomprensión para los no contemporáneos de esos mitos (tan rápidamente reemplazados por otros) $y$, consecuentemente, de la obra?

MP: Yo, mira, recuerdo muy bien un problema que tuve en la primera novela al nombrar al actor Pedro López Lagar en un capítulo que, al final, se eliminó, pero... de todos modos es importante esto. Yo lo nombraba como el galán favorito del personaje que hablaba, y un amigo me dijo: ¿por qué en vez de poner el nombre Pedro López Lagar no pones lo que significa para vos Pedro López Lagar, el concepto Pedro López Lagar? Eso responde un poco a tu pregunta, ino? No importa que una chica de Medellín de veinte años lea el libro y se encuentre ante ese fenómeno, porque si yo lo pinto bien, si yo ilustro al fenómeno Pedro López Lagar (en el caso de que aquel capítulo hubiese quedado), esta chica, si yo hubiese resuelto el problema literario, ella tendría que comprenderlo al mito...

JC: ... aunque el referente real, digamos ¿ya no exista?

MP: Claro, pero si yo le doy la esencia de Pedro López Lagar, ella tiene que comprenderlo. Allí está mucho del problema de lo efímero de ciertas obras, con referencia a la actualidad. Pero si tú te tomas el trabajo de, en vez de nombrar a Marilyn Monroe en tus clases, de darles la esencia, la tuya, claro, lo que significa para vos, bueno... no importa que la desconozcan.

JC: Sabemos de tu evasión mediante el cine, de tu cinemanía, pero ya concretamente en lo referido a la aplicación de técnicas cinematográficas a la narración, ¿qué podés decir?

MP: Hubo una escritura del capítulo primero de The Buenos Aires Affair, que después deseché, donde se notaba esa influencia. En él aparece la madre de la protagonista, una madre declamadora que rige su conducta de madre según las pautas, según la ideología de las madres de Gabriela Mistral, pero que, inconscientemente, desea que esa hija se muera y deje de provocar problemas, deje de sufrir. Ese sentimiento auténtico no lo puede concienciar, es demasiado cruel y no va, de algún

${ }^{12}$ Gillo Dorfles, Símbolo, comunicación y consumo (Barcelona: Lumen, 1967). 
modo, con su educación. Yo quería que esta mujer, al despertar y encontrar que la hija no está, tuviese un deseo inconsciente de que la hija no apareciera más. ¡Pero es la hija, una madre no puede desearle la muerte a su hija! A ese sentimiento esta señora no le puede dar cabida. Entonces, yo quería dar en ese capítulo la ambigüedad de sentimientos de esta señora. Se me ocurrió hacerlo en una tercera persona especial, una tercera persona maléfica, una tercera persona malintencionada, no subjetiva. ¿Cómo resolver la cosa? Yo recordaba ciertos usos de la cámara en cine, y después, viendo cierta película, pude individualizar una secuencia directa que influyó en mi novela. Es de la película Psicosis, cuya primera escena es el encuentro de dos amantes clandestinos en un cuarto de hotel. Es un cuarto pequeño y a ellos se los ve siempre a través de una cámara extraña, es una cámara que los observa como desde atrás del biombo o espiando por la ventana pero Hitchcock se ha preocupado muy bien, desde el principio de la película, de mostrarnos que no hay nadie más en el cuarto, sólo ellos dos. Así que el que los está observando no es un espía, no es un asesino, pero es una cámara extraña, «espiona». O sea, que hay cámaras objetivas y cámaras subjetivas correlativas de la tercera persona y de la primera. $\mathrm{Y}$ en el texto estaba el mal. El mal como deseo inconsciente en la madre que, al no poder racionalizarlo, lo convierte en algo oculto. Entonces había que narrarlo todo en tercera persona, una tercera persona que se regocija cada vez que encuentra un indicio, un detalle maligno. De ese modo la tercera persona se volvía una primera persona, un personaje pero, como no podía reaparecer después en la novela - debido a la economía de la obra-, me sobraba. O sea, que para dar esa sensación difusa yo elegí una tercera persona, que es una especie de diablo y que no reaparece más. Entonces, ¿qué hago con él? A la basura ${ }^{13}$.

${ }^{13}$ Decía Puig en una entrevista en 1973: «En el primer capítulo tenía que contar la desaparición de una chica que está tratando de salir de un surmenage en una pequeña playa atlántica durante el invierno, acompañada de su madre. Primero el capítulo consistía en un diálogo entre la madre y el comisario a quien denunciaba la desaparición. Ocurría que, inevitablemente, surgía un pintoresquismo del habla de esta mujer, profesora de declamación, que me ponía demasiado en el clima de mis novelas anteriores. Después pasó a ser un monólogo del personaje ante el comisario; como hay algo muy terrible que está por suceder, se me ocurrió escribirlo en primera persona, y quien hablaba era la Voz del Mal. Era tan extravagante este recurso que no causaba ninguna alarma la desaparición del personaje. Hubo muchos intentos más y finalmente quedó una especie de narración hecha por una cámara. Un poco la cámara subjetiva de Hitchcock cuando muestra la acción a través de los ojos del asesino. Es decir, la mirada de la cámara es la mirada del asesino.» J. di P., «Puig: la resaca que trae la marea» (Panorama, Buenos Aires, mayo de 1973), p. 63. 
JC: ¿Por qué abandonaste Coronel Vallejos?

MP: Lo de Vallejos..., sentí que había dicho suficientes cosas. Piensa que, después de todo, yo estuve nada más que hasta los quince años y después nunca más volví. Si hubiese regresado, hubiese sido diferente. Tal vez ahora, si hay una séptima novela, parece que va a ser porteña, de los años cuarenta.

JC: Te pregunto lo de Vallejos porque pensaba en otros lugares imaginarios, Yoknapatawpha, Santa Maria, Macondo o en el caso de otro escritor argentino, Diego Angelino, entrerriano que ahora vive en El Bolsón - ganó hace unos años el Premio La Nación con una serie de cuentos que transcurren en un lugar imaginario, Campo del Banco-y ahora Pomaire le acaba de editar una novela, Sobre la tierra, que vuelve a situarse alli. Pareciera entonces que no importa mucho si uno ha vuelto o si...

MP: Para mí, sí. Sí porque me urge hablar de los conflictos que se han producido después. No es que todos los conflictos quedaran reducidos a aquéllos.

JC: Uno de los rasgos de la literatura actual pareciera ser la constante lúdica, el juego con la forma. En tu caso...

MP: Sí, a mí me gusta jugar con la forma pero siempre que me ayude a desentrañar un contenido, un misterio. Jamás el ejercicio por el ejercicio mismo, la gratuidad: eso no, nunca.

JC: ¿De dónde viene tu uso de la literatura fantástica (el tema del doble, el pacto con los muertos, la lectura del pensamiento)? ¿Proviene de una cierta frecuentación de la literatura fantástica del cono sur o es, nuevamente, la reelaboración de elementos de los mass-media?

MP: Tú dices los elementos nuevos de mi última novela. Bueno, yo creo que tiene que ver con el cine fantasmagórico, no con la literatura fantástica. Porque hay una cosa esencial: el cine fantasmagórico funciona en la medida en que el realizador comparte esos miedos. Las películas de fantasmas...

JC: ¿Están hechas por fantasmas?

MP: No, no. Las películas que me gustan, las que me pueden haber influido, están hechas por gente que se ha asustado haciéndolas, en que es evidente que creen en ciertas pesadillas.

JC: ¿Y vos pensás que en la literatura fantástica, Cortázar, por ejemplo, él no cree en...?

MP: No sé en Cortázar, que es el que menos conozco, pero en Borges, en Bioy Casares hay un distanciamiento.

JC: Es muy intelectual.

MP: Sí, sí. Yo creo que en ellos el autor está a salvo. Ellos están 
a salvo, creo. Así que eso me distancia de la literatura fantástica argentina; tampoco la conozco demasiado.

JC: ¿De modo que el influjo viene del cine?

MP: Sí, sí, del cine fantasmagórico y, literariamente, de otras cosas. Por ejemplo, Diez indiecitos de Agatha Christie; allí hay otra actitud respecto del material, no hay una actitud intelectual, sino una actitud más inocente frente a la pesadilla, a la historia, a la aparición del fantasma. ¿Comprendes?

JC: Eso tiene que ver con estar involucrados o que creen en fantasmas...

MP: No, no es que crean, pero sí que los asustan. Hay un matiz, porque creer en fantasmas es creer en aparecidos, verdad?, es un fenómeno sobrenatural. Que te asuste una historia de fantasmas es otra cosa, puede significar que esos fantasmas puedan identificarse con miedos tuyos, con personajes reales a los que les atribuyes poderes fantasmagóricos.

JC: Seguramente conoces el artículo de Severo Sarduy «Notas a las notas a las notas. A propósito de Manuel Puig». ¿Qué te parece?

MP: Bueno, creo que es válido pero no porque ayude a entender mis cosas, sino porque tiene gracia autónoma, ¿no? Pero no creo que tenga mucho que ver con mi obra. Tiene que ver más con él que conmigo.

JC: ¿Por qué escribis novelas?

MP: Escribo novelas porque hay algo que no comprendo, un problema muy especial y entonces se lo achaco a un personaje, a un tercero $\mathrm{y}$, de ese modo, a través de ese personaje trato de aclararlo. La génesis de toda mi obra ha sido ésta: no me atrevo a enfrentar el problema directamente porque sé que hay defensas inconscientes, hay frenos que no me dejan llegar a ciertos enfrentamientos dolorosos. En cambio, a través de un personaje es mucho más fácil, todo se puede ver con mayor facilidad, y como todos mis problemas son bastante complicados, siempre se me ha hecho necesaria toda una novela para desarrollar un problema, nunca un cuento ni una película. Ahora, últimamente, estoy empezando con algo de cine, pero es muy lateral. Entonces, la elección de la novela no es deliberada, sino que es una forma que se presta al desarrollo de una actividad mía, casi de terapia personal. No hay libertad en esa elección, no es que yo elijo esto y no lo otro, sino que se impone. Tiene que ser una novela y no otra porque necesito mucho espacio; mi actitud es analítica, nunca sintética.

JC: ¿Vos vivis de la literatura?

MP: Sí, pese a que me han cerrado mi mercado principal, que era el 
de Argentina. Allí vendía mucho, realmente es un gran país consumidor de libros. Pese a eso, me defiende la cantidad de traducciones; no soy un best-seller impresionante en ninguna parte, pero... se acumulan regalías; tampoco he conseguido enriquecerme, por desgracia; me gustaría mucho conocer esa experiencia para después contarla.

JC: ¿Pero no te ves obligado a hacer ninguna otra actividad, aparte de escribir, para poder vivir, no?

MP: No. Yo empecé a enseñar en Nueva York —entré en la enseñanza a través de los talleres de literatura- por una necesidad muy curiosa: no tenía papeles para quedarme en Estados Unidos, y entonces la invitación de una universidad me solucionaba eso. $Y$ fue una sorpresa pues lo acepté así (aunque algo, una cierta curiosidad tenía por la cuestión), y la experiencia me resultó altamente satisfactoria; ahora me gusta esa actividad. Además, un taller normal, que abarca un semestre, no tiene por qué reunirse más que una vez por semana. De modo que no me quita tiempo, me distrae y me pone en contacto con los jóvenes. Así que es muy gratificante, a más de un nivel. Por otro lado, las películas que he empezado a hacer también -esto no debería decirlo porque los productores me van a querer pagar menos- me sirven como distracción. Una novela lleva de dos a tres años y me resulta muy positivo interrumpir por dos, tres meses un trabajo y pasar al otro. Ocuparme de un guión de cine que se soluciona tan rápido.

JC: Respecto de la noción de estructura en cine...

MP: La estructura, en cine, es fundamental. Se te tiene que ocurrir una historia capaz de ser contada en términos cinematográficos y, si haces una adaptación, concebir una estructura narrativa sintética. Hay una cuestión importante aquí. A mí el cine realista me interesa poco porque me parece que el realismo vive del análisis, de un tratamiento analítico. Yo estoy acostumbrado a un tratamiento novelístico detallado como modo de abordar la realidad, y, en cambio, el cine vive de la síntesis. ¿Y por qué el cine realista en general resulta poco efectivo al cabo de los años? ¿Por qué envejece el cine realista? Y ¿por qué el cine de Hollywood de los años treinta y cuarenta no se ha añejado también? Yo creo que hay una razón. Aquello era un cine de sueños, lo que se pretendía era darle opio al pueblo, sueños. Y el sueño y la síntesis van juntos. ¿Qué modelos de síntesis más perfectas que nuestros sueños nocturnos? ¿Son modelos de concisión, no?

El cine realista americano del presente a mí me parece que cae en una facilidad, una superficialidad... Se intenta comprender una realidad y lo único que se logra es fotografiarla. Creo que la mejor película de estos últimos años, estilísticamente válida, que ha logrado un cierto nivel 
artístico, es Chinatown ${ }^{14}$ de Polanski. Es una pesadilla. No es un intento de realismo. Al cine yo lo veo más cercano de la alegoría que del realismo, más cercano de lo onírico. Y las ideas que ahora se me están ocurriendo para cine tienen poco que ver con mi novelística. No son intentos realistas.

JC: ¿En cuanto al temor de que el cine desplace o, peor aún, reemplace la lectura de novelas?

MP: La novela es un modo de narrar y el cine también. Sin embargo, es preciso hacer un deslinde muy claro de campos. Es muy diferente la lectura de una película a la lectura de un libro. Son dos operaciones de la atención muy diferentes. En el cine hay una parte de la atención dirigida a la imagen, otra a la parte auditiva. Eso da como resultado cierta dispersión, en este sentido: ciertos discursos conceptuales muy complicados - para un señor muy adiestrado en la lectura, una lectura filosófica-, ese mismo discurso lo oye en cine y no lo puede captar. La lectura cinematográfica tiene que ver con la lectura de un cuadro y tiene que ver con la lectura de un libro. Entonces, no es ni una cosa ni otra, es una combinación, de modo que en cine se pueden hacer ciertos discursos, pero no se puede entrar en ciertas cuestiones analíticas complicadas porque hay un señor allí, en la platea, con un límite de atención que no se lo cambia. Eso es terminante. Supongo, entonces, que un tipo de discurso no molesta al otro. Son dos cosas distintas. De modo que a la literatura le queda entonces un campo absolutamente propio. Habría tal vez ciertos autores - un Hemingway, por ejemplo- con una visión algo exterior de los hechos, sin un discurso conceptual especial... Cierto tipo de literatura podría ser suplido, pero no creo que sea tan fácil, por eso no creo que haya conflicto entre los dos.

$\mathrm{JC}$ : Vos hablabas de una película italiana...

MP: Sí, una película italiana de hace dos o tres años: Il suspetto de Francesco Mazzelli, un hombre de izquierda muy serio, muy conceptual. Hizo esta película, que es una discusión sobre actitudes dentro del partido; en ella se dialoga mucho, se discuten cosas muy complicadas

${ }^{14}$ Cf. el análisis de Chinatown en Arnaldo Rascovsky, Cine a la luz del psicoanálisis (Buenos Aires: Schapire, 1975). Pregunta Rascovsky: «¿A qué se debe el significativo éxito de esta película que ofrece un contenido manifiesto truculento y violento, sazonado con los elementos comunes que se encuentran en la mayoría de las películas policiales?» (p. 77). Y más adelante responde: «En esta equiparación entre ética familiar y ética política reside uno de los más profundos aciertos de la película, porque contribuye a esclarecer en cuanto la organización familiar constituye la organización social genética y primitiva, que condiciona las caracteríșticas ulteriores de la ética política posterior» (p. 79). 
y el espectador se queda en ayunas. No puede seguir el hilo. Es demasiado complicado lo que se dice, uno está mirando a Annie Girardot, a Gian Maria Volonté, los gestos, viene toda esta discusión, el de al lado se mueve, alguien quiere pasar por la fila... No sé. Aunque fuera el público más educado del mundo y el más silencioso, imposible seguir la película. Mazelli hizo, yo creo, un intento muy honesto de hacer cine inteligente, pero ¿qué pasa? Que no, la atención del espectador no da para eso. Yo vi la película y no entendí nada, bueno... entendía parte, pero me perdía constantemente. Pedí el guión, lo leí, era muy fácil de seguir en la lectura. Había algún punto un poco denso, un poco difícil, volvía atrás una página, lo releía. Así $I l$ suspetto me quedó muty claro. Ese me parece un ejemplo perfecto de lo que sucede.

JC: Es evidente el valor que tienen para vos actrices como Rita Hayworth, Norma Shearer, Hedy Lamarr, Greta Garbo, Dorothy Lamour, Bette Davis, pero, respecto del cine argentino, sólo encuentro mencionada a Mecha Ortiz.

MP: Es cierto lo de Mecha Ortiz. Respecto de las otras, mirá, por ejemplo, las hermanas Legrand -Mirta y Silvia-; ellas eran la respuesta argentina a Diana Durbin y la moda de las «ingentias». No las podía aceptar porque las tenía cerca y odiaba cosas de ellas: las Legrand eran chicas que se casaban vírgenes y de blanco... Además, pretendían que el varón que se les acercaba las tratase de determinada manera, con gesto de mando, imponiéndoles una distancia, cierto respeto. En cambio, había una actriz argentina que yo sí respetaba, ésta era una mujer que hacía siempre de mujer fatal, una mujer con un pasado, una mujer superior, muy segura, con experiencia de la vida. Una mujer que yo no veía en la realidad, así que desde el momento en que era irreal, a mí me venía bien, yo la podía querer porque no se parecía a nadie. Me aferré a ella y era la única argentina que me gustaba. Esa era Mecha Ortiz.

JC: Sigamos hablando de cine, pero demos un salto en el tiempo. ¿Te acordás de la cálida recepción que generó en Argentina Hiroshima mon amour $y$, en especial, El año pasado en Marienbad, junto con todo el nouveau roman? ¿Cómo te explicás vos eso? Ah, y otra cosa, en algún momento, al leer el primer capitulo de La traición de Rita Hayworth, pensé que alli habia ecos de esas «voces banales» tan frecuentadas por los autores del nouveau roman y por Nathalie Sarraute en especial.

MP: Bueno, en aquella época —-como se hablaba de una nueva percepción de la realidad - se dio gran crédito al movimiento y logró unas respuestas increíbles, las primeras obras del nouveau roman eran leídas con total devoción. Hoy el nouveau roman es un movimiento casi 
terminado. Había una preocupación por el aspecto formal únicamente. Lo que se proponían era una revolución de la forma, una nueva percepción formal y cometían lo que creo que es un error básico: posponer el contenido a la forma. Estaban convencidos de que ya no queda nada por decir, todo se ha dicho, la única salvación está en replantearlo de otro modo. No sé, en un país como Francia - un país viejo- esto se concibe: ellos cargan con tanta gente genial a sus espaldas, que ya se ha expresado anteriormente, que tienen que sentirse con ese peso. ¿Quién escribe en francés después de Proust, de Flaubert? Nosotros, en ese sentido, estamos a salvo, no tenemos esos gigantes, esas sombras tan tremendas. Lo que pesaba sobre los franceses era eso, no que les faltasen cosas que decir. Por ejemplo, no hay una gran novela sobre la ocupación alemana. No es que falten temas, siempre están sucediendo cosas - este conflicto de la ocupación, por ejemplo-, y, sin embargo, no se interesan por contar ese tipo de cosas. Como enseñanza se podría extraer - de la experiencia del nouveau roman - la de nunca anteponer una preocupación formal a la otra; lo importante es la necesidad de investigar algo por una necesidad de cambiarlo, la forma viene sola.

Respecto del cine, pasó lo mismo, en especial $E l$ año pasado en Marienbad. Todos íbamos a ver la película porque habíamos leído a Robbe Grillet o Los frutos de oro de Nathalie Serraute, dándole total crédito. Y como además era un tipo de exposición vaga, daba lugar a la proyección personal del espectador. También ayudaba en ese entonces la protagonista - desconocida-, sobre cuyo rostro se proyectaba todo. En ciertos momentos era como si la pantalla quedase en blanco y cada uno proyectase su interpretación. Y como era total la confianza en esta nueva escuela, que nos iba a revelar el mundo, la proyección era una proyección positiva. Se entraba al cine con una humildad total, estando de acuerdo de antemano con las revelaciones que nos iban a dar. Esa complicidad del espectador convertía a la película en una maravilla; ahora ya no. Yo la volví a ver hace poco en Estados Unidos, y todo el mundo, cuando la protagonista decía "L'année dernière...», se reía; ahora resulta ridícula.

En cuanto a tu pregunta sobre el primer capítulo de La traición..., bueno, yo no partía de ningún principio teórico, sino sólo intentaba reproducir algo real, el modo como mi tía y otras mujeres de la familia hablaban. El origen, como ves, es otro.

JC: Otra cuestión interesante, relacionada con lo que vos decías acerca de tu intención de investigar el error argentino -error politico y error sexual-, sería la de las diferencias entre ensayista y novelista.

MP: Hay una diferencia en la actitud. El ensayista tiene que seguir 
una cierta racionalidad, ajustarse a una disciplina. El novelista tiene la ventaja de poder usar la fantasía y de ser subjetivo, de identificarse con lo que se trata. Yo creo que, en la medida en que el novelista comparte con el protagonista, con el personaje, su problema y logra establecer una línea directa a su inconsciente, allí puede expresar misterios muy escondidos. Pero para eso se necesita una total libertad.

JC: ¿Libertad política?

MP: Sí, ante todo, política. Para un ficcionista, para alguien que trabaja con fantasías y, por ende, con el inconsciente, es básico —si quiere ser honesto- tener libertad, no sólo ideológica, sino total independencia de partidos, de partidos políticos. Puede tener ciertas ideas políticas pero un compromiso con cuestiones concretas que le aten las manos y que le frenen la imaginación, no. Yo creo que conviene estar un poco al margen y, de ese modo, se puede hacer un aporte. No somos la gente más dotada para la acción, no creo que nuestro aporte vaya por ese lado; en cambio, un compromiso total con la verdad, con la verdad propia, individual, es fundamental. Esa fantasía en libertad puede ir y señalar dónde está la llaga, el núcleo represivo. ¿Qué puede más: una intuición poética o una obra racional? Yo creo que podría hablarse de acciones complementarias. $Y$ supongo, no sé si será para defender mi caso, que cuanto más se compartan esos problemas, cuanto más uno esté sumergido en la problemática que se está tratando, cuanto más se esté a la altura de los personajes, más posibilidades hay de revelarlos, de conocerlos.

JC: De modo que la relación entre acción y obra, arte y politica...

MP: Yo creo que los escritores no somos gente muy seria... La seriedad, la disciplina va en el trabajo, pero somos muy impulsivos, tenemos que serlo, porque si no..., ¿dónde está el temperamento del escritor, no? Creo que eso se debe a una cierta falta de objetividad. El escritor tiene que estar siempre actuando de acuerdo a un mundo propio, a una óptica propia. Si no tiene una óptica propia y un mundo propio, no es un creador, ¿no? Entonces, en razón de esa impulsividad, de esa subjetividad necesarias, no creo en una objetividad ideal. Por eso desconfío mucho de mis colegas. Por otra parte, no creo que estemos dotados para la acción.

JC: Vos, como escritor, ¿qué consejo podéis darle a los jóvenes que se inician en la creación literaria?

MP: Bueno, el otro día -en el taller literario de la Biblioteca Pública Piloto, que dirige Manuel Mejía Vallejo- Rulfo aconsejaba a los escritores que se inician que deben leer mucho. Yo no estoy de acuerdo. Yo creo que sí, que la lectura puede afinar la puntería, permitir estar 
al tanto de lo que se está escribiendo, de lo que se está haciendo, pero, a veces, ese afán de información puede ser inhibitorio. Porque si se está demasiado consciente de lo que hacen los demás, entonces no queda lugar para la preocupación por lo propio. A veces yo creo que una total alienación, un sumergirse en los problemas propios y olvidarse de todo lo demás, tratar de expresar lo propio — como sea-, puede resultar más beneficioso, más liberador que ver qué es lo que están haciendo los otros para no hacer yo lo mismo.

JC: Al respecto recuerdo algo que Dario Ruiz Gómez planteaba esta mañana acerca de la necesidad de diferenciar información, o estar «al dia», y el hecho de manejar toda una cultura contemporánea. Citaba el caso de García Márquez, que escribió excelentes crónicas de cine y artículos sobre Virginia Woolf, Faulkner, etc., y que -cuando se volvió famoso- dijo que él nunca había visto cine ni leído literatura. Según Dario, esto constituyó un ejemplo muy dañino, ya que mucha gente pensó que escribir era sentarse a escribir y que lo demás venía solo, espontáneamente. $Y$ señalaba también la diferencia entre Colombia - «un país muy retórico" - y Argentina, con toda una tradición cultural: cine, literatura, editoriales.

MP: Es posible. En la Argentina, el problema era el gusto por lo cerebral; todo lo que implicaba sentimiento, sensaciones, intuición era dudoso. Lo prestigioso era lo cerebral, así como en la conducta tenía mucho más prestigio la reserva, la mesura. La estridencia, el exceso, ijamás! Lo español y lo italiano —en la Argentina- era considerado de clase baja; en cambio, tenía un gran prestigio lo inglés - que era siempre lo medido- y lo francés, en segundo término. Un país totalmente adolescente, país formado por una gran masa de inmigrantes - de principios de siglo - y cuya actitud era, pretendía ser, la de adultos. Gustaba mucho el cinismo epigramático - a lo Oscar Wilde-. Eso no correspondía en absoluto a la realidad de la gente: un pueblo adolescente, inmaduro, que no se conocía a sí mismo, que no sabía quién era... Pero las actitudes eran siempre de adulto, muy seguro de sí mismo, muy controlado. Gustaba mucho el autocontrol, la represión. Para un adolescente, en cambio, lo más saludable es expresar sus excesos, sus estridencias, su exceso de energías y allá era todo lo contrario - lo inglés, como paradigma-, algo tan alejado de nosotros. Así, por ejemplo, lo norteamericano, del cuarenta y cincuenta, era mal visto; al argentino no le estaba permitido identificarse con otro país joven, en busca de su identidad. No gustaba Faulkner. Borges lo tradujo, pero no se lo consideraba aporte importante. $\mathrm{Y}$ al cine norteamericano tampoco.

JC: En relación con esto, planteado en forma opuesta por vos y 
Dario, yo pienso en mi experiencia como profesora de literatura en la universidad, en Argentina y en Colombia. Allá, en el sesenta y setenta (primero como estudiante, luego como profesora) yo veía que los alumnos no escribían demasiado; a lo sumo, trabajos de crítica literaria muy ceñidos a los cánones europeos (alrededor del setenta y dos, con la inminente vuelta del peronismo, se generó otra situación -que no duró mucho- $y$ que consistia en el interés por una crítica latinoamericana con patrones propios, capaz de expresar una realidad cultural propia: el boom, el nuevo cine brasileño y argentino), pero trabajos de creación, muy raros. Cuando vine acá, en el setenta y siete, me encontré una realidad muy distinta: acá todo el mundo escribe -en especial, poesía-. Si te descuidas, no te alcanza el día para leer efusiones manuscritas que, lo menos que se puede decir, es que necesitan decantarse, ser vueltas a mirar por los autores con ojo crítico, objetivamente, a la luz de la literatura contemporánea. Se trata en general de textos saludables tal vez como catarsis personal, pero artísticamente... ¿Por qué este fenómeno? Yo creo que, en Argentina, un exceso de conocimiento, de información (que como vos decías puede llevar a la dispersión, a la pérdida del propio centro), puede llegar a esterilizar el impulso de expresión personal, el intento creador. Acá todo lo contrario: la falta de buenos modelos, nacionales y extranjeros, o la falta de su frecuentación, creó una falsa idea de total libertad, de que lo bueno es lo espontáneo, la "sinceridad» en una época en que sabemos ningún escritor que se precie de serlo puede darse el lujo de ser inocente. Después de Proust, Joyce, Pavese, Virginia Woolf o, en Latinoamérica, de Borges, Cortázar, Onetti, Puig, García Márquez. Creo, resumiendo, que allá —en el cono sur-un exceso de información y de conocimiento (a veces no digerido) esterilizó; acá, por el contrario, un total desconocimiento dio como consecuencia un gusto y una práctica por la improvisación, el espontaneísmo. Tal vez las declaraciones de Garcia Márquez hayan contribuido a ello, no sé.

MP: Para terminar esto de los consejos a los jóvenes escritores, yo creo que tener una información está bien, pero que eso, saber lo que están haciendo los otros, no se transforme en una obsesión. Es necesario no anteponer nunca la preocupación formal a la otra. Lo importante es una necesidad de investigar algo, una realidad o la necesidad de cambiarla. Creo que todo está allí.

JC: Quisiera que hablaras de tu experiencia en talleres literarios en Estados Unidos.

MP: Puedo contarte mi experiencia en el taller literario del City College en Nueva York. No he visto peor situación que la del escritor joven en Estados Unidos, porque está tan industrializada la cuestión edi- 
torial que no cabe cierta cuestión artesanal, que todavía se usa en Latinoamérica y en otros países del mundo, en España, por ejemplo. Es toda una cadena de cuestiones: es muy caro editar, no se puede trabajar de modo underground o semiprofesional porque las librerías no le toman el material. Esto se debe a que la gente está tan condicionada por la publicidad, por los lanzamientos; está tan ocupado ese espacio por el bombardeo de anuncios (el lanzamiento de una novela comercial - por ejemplo, Cheever, algo tiene, pero no es mucho, pero es lanzado como la "octava maravilla», este tipo de lanzamiento no sucede en otros países), que no pueden leer otra clase de cosas que ésas. Para nosotros, los latinoamericanos, sale un libro y los anuncios no cuentan, es otra vía -más adecuada a la naturaleza del producto-: la crítica de un amigo, una crítica que apareció, el consejo del librero, etc. Allá nadie va a una librería a mirar qué hay y tampoco el librero es especializado (es un «chico» cualquiera que vende una mercancía). Ser librero no está codificado como especialización; el empleado no sabe nada en absoluto. Se compra lo que se ha visto anunciado, y que es un libro de "tapa dura»; eso es lo que se lanza y que, tradicionalmente, sirve como regalo. Sólo en un segundo momento, si se ha visto un interés posterior, viene la edición del libro en rústica. De modo que el joven escritor en Estados Unidos sabe todo esto: si no hay forma de comercialización, no puede llegar a las librerías; en consecuencia, no hay espacio para una literatura experimental. En Latinoamérica, en cambio, todavía existen las pequeñas editoriales, que pueden subsistir; allá no. En los jóvenes escritores norteamericanos se nota cierto desencanto, cierto desangramiento. En los latinoamericanos todavía tiene algún sentido luchar contra la censura, porque nuestros sistemas gubernamentales son, de algún modo, vulnerables. Eso, al escritor, le da cierta identidad: «Me censuran, luego existo.» Es un estímulo. En Estados Unidos no, no hay la menor censura para el escritor; la fuerza del sistema, su afianzamiento es tal, que la tarea del escritor no incide para nada, no tiene la menor gravitación. Ese desencanto - propio de los alumnos norteamericanos del City College- contrasta con los alumnos de la Columbia University - latinoamericanos-, que todavía alientan la ilusión de cambiar el mundo; en ellos se da la vinculación de la propia neurosis, referida a un sistema que se intenta de algún modo cambiar, con la creación literaria.

JC: Volviendo a tu obra, ¿cómo ves la relación entre tu horror a asumir la narración en tercera persona y la crisis del narrador en la novela contemporánea?

MP: Bueno, yo, cuando empecé a escribir mi primera novela, no tenía en absoluto planteado el problema: voy a escribir en primera o en 
tercera persona. Empezando porque no había pensado en hacer una novela, sino un guión, así que eso ni remotamente lo pensaba. Pero, para aclarar mis personajes, intenté hacer una descripción de cada uno de ellos antes de empezar a armar el guión. Entonces empecé a recordar cómo hablaban ${ }^{15}$, qué decía esa tía mía que tanto me había regañado, y... cuando llegué a la página treinta me di cuenta de que allí sí, por primera vez, estaba trabajando un material que era legítimo, nadie me podía decir que eso era una copia de películas ya vistas. Eso lo noté como mío, y, como material, era entonces irreprochable. Dirían las tonterías que dijeran, pero era, había sido, así. Si cometían, además, errores de sintaxis y gramática, eran errores de ellos. Yo no tenía nada que ver. Surgieron así los monólogos interiores, que, en un determinado momento, amenazaron con repetirse, con volverse reiterativos, y así se volvía casi imposible diferenciar al adolescente, al viejo, a dos personajes de la misma edad, sexo, misma clase social. Entonces se me aconsejó que diversificara la técnica. Debía dejar el monólogo interior y usar otros medios. ¿Qué hacer? ¿Usar una tercera persona? iJamás! No podía asumir esa responsabilidad. Salí del paso imitando la escritura de esos personajes: en vez de reproducir su habla, ver cómo ellos habían escrito una carta, un diario íntimo, una composición escolar. Así terminé esta primera novela sin haber escrito una sola línea en tercera persona. No sabía entonces que estaba coincidiendo con una crisis mundial del narrador, era justo el momento en que en Francia se proponía el nouveau roman.

JC: ¿Y en la segunda novela?

MP: En la segunda novela ya estaba de regreso en la Argentina, ya había logrado otra familiaridad con el idioma y me animé a una tercera persona, a incluir pasajes en tercera persona, pero - para entoncesya había concientizado muchas cosas. Mi resistencia a escribir en tercera persona no era sólo una debilidad de carácter, sino que coincidí, como te decía antes, con la crisis del narrador, ¿no? Entonces me sentí inscrito en una corriente y me di cuenta también de la absoluta imposibilidad de ser objetivo. Entonces, en los pasajes en tercera persona de esta segunda novela, me interesaba justamente llevar la crispación de esa tercera persona - del deseo, del ansia, del afán de objetividad de esa tercera persona-, llevarla a su última consecuencia, para demostrar su falsedad. Entonces son pasajes de una frialdad, de un distanciamiento

${ }_{15}$ «En mi corta experiencia de narrador he comprobado que saber cómo habla un personaje es saber quién es, que descubrir una entonación, una voz, una sintaxis peculiar, es haber descubierto un destino.» J. L. Borges, El Martín Fierro (Buenos Aires, Ed. Columba, 1960), p. 11. 
que... se vuelven cómicos. De modo que mi primer contacto con la tercera persona fue así: yo totalmente a la defensiva, no creyendo en la posibilidad de una objetividad. Entonces ahí sí la elección de las palabras me fue mucho más difícil porque esa elección estaba al servicio de un tipo de búsqueda más mía, ya no era cosa que yo compartiera con el personaje. Era una búsqueda formal. Tuve que precisar más, buscar más... Además de esta tercera persona general, y ya, de tan pretendidamente objetiva, irónica, cómica, empleé cartas, muchas cartas y otras técnicas.

JC: ...

MP: Había un momento en que tenía que pintar el regreso de un personaje, pero... ¿cómo hacerlo? Otra vez esa tercera persona gélida, no; no me convenía en ese caso porque yo quería dar una emoción. Es el muchacho que vuelve del sanatorio de la montaña al pueblito natal, en colectivo. ¿Cómo lo pinto? Y se me ocurrió que cuando uno va en ómnibus y mira por la ventanilla tiene una experiencia muy especial de acumulación, de enumeración, enumeración de cosas: casa, vaca, poste, paisano, árbol. Pasan así ante la mirada. Entonces, ¿por qué no hacer una enumeración, simplemente? Cinco o seis páginas de enumeración, de cosas que van pasando delante de la mirada de este hombre, pero... había que hacer expresiva esta enumeración. Está servida la solución: lo que él nombra es aquello que, de algún modo, le interesa, le molesta, le implica. Entonces hago la enumeración tratando de meterme en la cabeza del personaje, y ése es uno de los capítulos más fáciles que escribí. Por desgracia es un recurso que no se puede repetir.

JC: ¿Y el del álbum de fotos como medio de suplir la descripción tradicional de los personajes?

MP: En busca de esa objetividad tan ansiada del siglo pasado, ¿qué mejor que las fotografías, que sí son objetivas? Y ahí está, entonces, la objetividad de un álbum de fotografías: es feroz, se hojea y ahí están las cosas. Claro que yo, al describir el álbum, voy a anotar lo que me interesa a mí y voy a dejar pasar otras cosas. Inevitable la subjetividad, pero, de algún modo, se logró plantear esto, y, al mismo tiempo, señalando - dentro de esas fotos descritas-, poniendo en evidencia detalles muy dicientes que yo consideraba así. De ese modo lograba cierto juego irónico con detalles insignificantes.

JC: ¿Y el uso de lenguajes de «segunda mano»?

MP: Bueno, otro modo de atacar, de ir hacia el inconsciente, se me ocurre que es el examen de los lenguajes de segunda mano. Y cómo accedemos a ellos, cómo llegamos a emplear un lenguaje judicial, un lenguaje rural, un lenguaje médico. Allí hay juegos muy especiales, es- 
tamos aceptando un código que no es el nuestro y que — de algún modo- tiene que ver con esas máscaras de la conducta. La expresión de hechos muy simples tras un código verbal muy aparatoso, de algún modo me parece que nos refiere al enmascaramiento de ciertos actos que se originan en una necesidad muy simple y que aparecen enmascarados, deformados.

IC: ¿Y la influencia de los mass-media en el lenguaje?

MP: Bueno, por ejemplo, en mi primera novela, aquel primo mío que iba a ser su protagonista pasó a personaje secundario porque mi personaje pasó a ser el centro de la novela. Mi personaje estaba totalmente condicionado por el lenguaje de las películas, por los personajes de las películas, y ése era un lenguaje alienado. Yo podía comprender —en la vida, el lenguaje y la conducta de alguien, en la medida en que se pareciese a un personaje de película-. Entonces sentía mucha afinidad por la gente que estaba «marcada» en su lenguaje y en sus actitudes por la influencia del cine, del cancionero. Si bien los personajes están determinados por el cine, ya hay un personaje que apunta hacia los otros tipos de alienación. $Y$ en la segunda novela a mí me interesaba mucho tratar el problema de la clase media argentina ${ }^{16}$, de la clase en que yo había nacido. Y esta gente tenía una total adhesión a la ideología de las canciones: repetían letras de tangos y boleros - que suelen ser muy populares en los pueblos-. Y se creían que actuaban de acuerdo a esta ideología de la "gran pasión», de sacrificarlo todo por el amor, pero, en realidad, la cosa era mucho más fría y calculada. Se daba así una escisión entre esa «ideología de la gran pasión» (cancionero, radioteatro, novela rosa, cine) y el cálculo, la mezquindad en el plano real. En el proletariado esto no sucedía.

JC: Al respecto, vos esbozabas, el otro día, una teoría del habla en Argentina...

MP: Sí. Hay que recordar que en Argentina, la gran masa de la población se forma a principios de siglo y la forman inmigrantes (campesinos, que hablan gallego, catalán, vasco, italiano, polaco). Esos inmigrantes quieren ingresar a una clase media, ser pequeños comerciantes, empleados, y a los hijos no les pueden pasar ningún bagaje cultural, y ni siquiera les pueden pasar un idioma. Esos hijos tuvieron que aprender el español en la calle: todo lo de la casa era «dudoso», lo de la casa no convenía porque era cosa que ya se estaba superando; enton-

${ }^{16}$ Cf. Ricardo Piglia, «Clase media: cuerpo y destino (Una lectura de $L a$ traición de Rita Hayworth de Manuel Puig)» (Nueva novela latinoamericana, Buenos Aires: Paidós, 1972), tomo II, pp. 350 y ss. 
ces los modelos del lenguaje a mano eran los del cancionero, los de la mala prensa, los del folletín que circulaban en aquella época, y era siempre un lenguaje «cargadísimo», un lenguaje irreal, altisonante, demasiado florido. E1 lenguaje del tango, por ejemplo, ¿por qué el lenguaje del tango es siempre tan truculento? Porque está dirigido a gente muy simple, a la que hay que impresionar con efectos, y que, de algún modo, es un lenguaje difícil de repetir porque no es real. El argentino entonces, el argentino de primera generación y sus hijos, ve que hay un lenguaje de «entrecasa» que incluye formas dialectales y que sí es espontáneo, y otro, el lenguaje de la calle, que se usa cuando llega el momento de expresarse: una declaración de amor, escribir una carta, discutir algo en el bar. En ese momento se echa mano a un lenguaje cultural, con base en esos modelos.

JC: Hay una imagen de tu exposición en el Paraninfo, referida a tus padres, y que creo que constituye una parte importante de lo que Mauron llama «mito personal», que a mí me impresionó fuertemente. Vos decias: "Habia una pareja -una señora muy educada, que era doctora en quimica, que venía de la ciudad, muy despierta, muy práctica, casada con un señor que no tenía la educación de ella, pero tenía otra, y tenía otras virtudes: era un hombre de gran imaginación-. Yo ya veia que, de algún modo, esa señora que tenía educación no podía demostrarla porque le había tocado el papel de una señora sumisa, a la vez que el señor, que era muy inseguro (porque alguien con esa imaginación no puede ser seguro, se le ocurren mil posibilidades a cada paso, a cada situación), le había tocado el papel del macho seguro.» En esa visión recuperada de tu infancia, respecto de tus padres, vos planteas el problema de los roles, ¿no?

MP: A mí siempre me interesó dilucidar el problema este de los roles: un rol se asume, pero de la manera más inconsciente, y no es que esto esté ahora ya totalmente claro, al contrario. Esto es muy reciente, muy nuevo. Antes se creía que era natural eso de seguir ciertos comportamientos, de repetir al infinito este binomio hombre fuerte/mujer débil, y a mí me interesaba sobre todo, y me sigue interesando, ver en qué momento el rol se impone. $Y$ todo esto está en el campo del inconsciente.

JC: $Y$ en Pubis angelical...

MP: Pubis angelical ya lleva esta búsqueda al extremo. La novela se divide en dos partes: una en la que cuento toda la vida consciente de la protagonista - es una muchacha que está enferma en México, una argentina exilada-, y allí pongo lo que ella habla, lo que escribe en su diario íntimo, es decir, todo aquello que ella puede controlar, lo que está en su conciencia, los contenidos conscientes. Por otro lado, como una 
historia paralela que cuento, está lo que yo supongo que son sus fantasías más secretas, fantasías que ni siquiera ella se atreve a enfrentar, a asumir. ¿Y qué pasa con la búsqueda, con el enfrentamiento con los materiales inconscientes? No hay terreno más resbaladizo, no hay imágenes más huidizas que las del inconsciente. El inconsciente no admite un tratamiento frontal porque su carácter es el del encubrimiento, el de disfrazarse. ¿De qué manera se manifiesta este inconsciente? Allí está el trabajo ${ }^{17}$. Como decía antes, ciertas pautas fijas muy populares, ciertos mitos, encarnan contenidos del inconsciente colectivo y - no por nadatienen esa fuerza y esa duración. El mito de Elvis Presley, de Grace Kelly, son cuestiones que tocan la imaginación de la gente, tienen que ver con problemas nuestros. Todo el enfrentamiento con este material es lo que me lleva a ciertas experimentaciones.

JC: El problema de esos mitos —o la encarnación de esos mitosvarían en el tiempo. Por ejemplo, en Pubis, la introducción de Hedy Lamarr a mi me desconcertó: ¿responde a una realidad de la protagonista - una mujer argentina que en 1975 va a cumplir treinta años-o es un mito tuyo, del autor?

MP: Ante los mitos colectivos actuales - los Beattles, por ejemployo me siento en incapacidad de compartirlos. Yo estoy anclado en una época. Yo puedo hablar de Rita Hayworth, Clark Gable, Hedy Lamarr, del mito de los futbolistas que son alejados de sus esposas antes de jugar

${ }^{17}$ Dice J. Manrique Ardila acerca de Pubis: «... el documento más revelador que se haya publicado en Latinoamérica acerca de la condición de la mujer contemporánea»; en esta ocasión Puig define el tema central de la novela como «el despertar de una conciencia femenina». Y continúa diciendo: «La protagonista es una mujer de treinta años criada según los cánones de una clase media represiva que la destina a objeto sexual. Esta muchacha enferma fuera de su país y entra en crisis. No puede sustraerse al llamado de los movimientos feministas pese a sentir un gran rechazo por algunos de sus planteamientos. El conflicto entre dos visiones de lo femenino la asalta, y creo que actualmente hay muchas mujeres en la misma condición.»

Respecto del nivel inconsciente y los mitos colectivos: "Yo creo descubrir la presencia del inconsciente colectivo en manifestaciones de la cultura popular que han fascinado a las masas: cancioneros, mitos cinematográficos pueden of recer una pista. En este segundo nivel de la novela, el del inconsciente, me sirvo de fantasías que siempre tienen por núcleo a una mujer objeto vista con lente de aumento.» Y pregunta JMA: "Jung habló del ánima como la cualidad femenina del hombre. En su obra lo femenino siempre está equiparado con la bondad, lo bueno, mientras que lo masculino representa la opresión, las torturas, la brutalidad, ¿no es así?» MP: "Más que lo beatífico femenino lo que creo ver es lo diabólico masculino; creo que la hipertrofia de lo masculino origina el síndrome nazifascista.» JMA: «¿Eso lo ve a nivel latinoamericano o del resto del mundo?» MP: «A nivel mundial.» 
los partidos. Yo tengo ese tipo de fantasías, pero no manejo los actuales. Eso, es cierto, es una limitación espantosa.

JC: Sin embargo, ¿la introducción de elementos de ciencia ficción no podría demostrar lo contrario?

MP: Bueno, allí tiene características de una pesadilla que le sobreviene a la protagonista, una mujer muy bonita que ha sido criada para objeto sexual, para agradar al hombre, casarse bien con un hombre que la llene de cosas, pero a cuyas órdenes ella permanece. Ha sido criada para eso, pero ella se rebela, no se rebela su conciencia, sino que se rebelan sus órganos. Se casa con un hombre que la trata así y, en un determinado momento, deja de sentir placer. $Y$ uno de sus miedos inconfesados es el de, en una sociedad socialista, seguir siendo objeto sexual, aunque sea durante un año de servicio sexual obligatorio. Se me ocurrió que ése podría ser un terror no confesado de la protagonista.

JC: ¿Cómo han recibido los movimientos feministas tus novelas, y en especial la última?

MP: Los movimientos feministas, hasta la aparición de Pubis angelical, han recibido bien mis novelas. Esta última, en cambio, como va muy directo al problema feminista, ha despertado oposición. Se me achaca que pongo como ejemplo de mujer una mujer no muy fuerte; se me achaca que no sea un ejemplo claro, ya que es una mujer conflictuada, que trata de resolver su problema: ella quiere gozar con el hombre, pero no sabe cómo. La objeción que se me hace es que se trata de una mujer no muy inteligente, pero yo creí que ésa era una forma de que el lector se hiciera cargo del problema, si lo vivía en alguien no terriblemente dotado para resolverlo, ¿no? Por ahora en España hay un grupo que condenó la novela; no sé qué pasa con las feministas mexicanas ${ }^{19}$.

JC: Tengo curiosidad por saber de la novela que estás escribiendo.

MP: Bueno, vos sabés que a partir de la tercera novela me empiezo a ocupar de problemas recientes: Buenos Aires, el exilio en México (donde pasé los dos primeros años de exilio) y ya después paso a Nueva York. Y de ese modo lo que se me impuso para la nueva novela fueron los años pasados en Nueva York, o sea, 1976-1977, que fue en realidad una experiencia muy desagradable. Llegué a Estados Unidos - donde había vivido en el sesenta- en enero de 1976, sin papeles, sin departamento, con unos años más y a una Nueva York menos acogedora que

${ }^{18}$ En una carta de noviembre de 1979 me dice: «Pubis anduvo bien de ventas (muy) en México, pero tuvo críticas horrendas, todas de hombres (?). El movimiento feminista de allí (muy grande) se quedó callado, me les quejé mucho y espero que hayan reaccionado, veremos.» 
antes. País que sale de la euforia hippie (intento de liberación muy importante y que fracasó, se acabó), llegué a una ciudad derrotada, y a eso se sumaban mis problemas personales. De modo que el 1976 fue un año negro, espantoso. Tuve entonces un choque muy violento con un personaje norteamericano fascinante. Fue un problema vivido en inglés y yo quería escribir sobre eso. Le pedí permiso al personaje ese para tomarle notas sobre su vida: tomé como doscientas páginas de notas en inglés, y ahora estoy tratando de resolver esa cuestión. Antes, el lenguaje era vehículo de psicología y de caracteres, un lenguaje del que tengo todas las claves; ahora tengo todos los datos de un idioma del que no tengo las claves. En esta novela no me intereso yo como personaje, sino que la contrapartida del norteamericano es mi papá. El norteamericano es un muchacho de izquierda que rechaza todo el sistema en el que está inmerso y después, de algún modo, aplica en su vida de relación toda la acción represora que él critica. Es un caso que no pude dejar escapar: es un personaje tan emblemático, tan interesante. En la novela, mi papá llega exiliado a Nueva York y se enfrenta con este muchacho, que es sociólogo y que, despedido de todas las universidades, pasó a ser mesero, jardinero, cuidador de gente de edad. Mi papá, decía, llega exiliado y este muchacho lo lleva en su silla de ruedas. El inglés de mi papá es defectuoso, el otro no, son las notas. Entonces se me ocurrió intentar, para el muchacho, un castellano de traducción, desangrado, ficticio. Reconozco que es una empresa un poco demente, pero... bueno, así se dio.

JC: Una última pregunta: ¿por qué el trópico es un tópico en tu obra?

MP: Sí, lo es porque yo siempre cuento la cuestión esta de la ausencia de paisaje en la pampa. Para mí siempre la máxima aspiración era la de yivir en el trópico.

JC: ¿Un poco el paraíso localizado, no?

MP: Sí, sí, exacto. 